\title{
Biostimulants in the Indicators of Yield and Industrial and Chemical Quality of Oat Grains
}

\author{
José Antonio Gonzalez da Silva \\ Agrarian Studies Department, Regional University of the Northwest of Rio Grande do Sul, \\ Street of Comércio 3000, Universitário, Ijuí/RS - Brazil \\ E-mail: jagsfaem@yahoo.com.br
}

Ângela Teresinha Woschinski De Mamann (Corresponding author)

Federal Institute of Education, Science and Technology of Rio Grande do Sul, Street

Nelsi Ribas Fritsch, 1111, Neighborhood Esperança, Ibirubá/RS - Brazil

Tel: +55 (55) 99999-5794Ｅ-mail: angela.mamann@ibiruba.ifrs.edu.br

Osmar Bruneslau Scremin

Exact Sciences and Engineering Department, Regional University of the Northwest of Rio Grande do Sul, Street of Comércio 3000, Universitário, Ijuí/RS - Brazil

E-mail: osmarscremin@ @otmail.com

Ivan Ricardo Carvalho

Agrarian Studies Department, Regional University of the Northwest of Rio Grande do Sul, Street of Comércio 3000, Universitário, Ijuí/RS - Brazil

E-mail: carvalho.irc@gmail.com

\section{Laura Mensch Pereira}

Agrarian Studies Department, Regional University of the Northwest of Rio Grande do Sul, Street of Comércio 3000, Universitário, Ijuí/RS - Brazil

E-mail: lauramensch@gmail.com

Andressa Raquel Cyzeski de Lima

Agrarian Studies Department, Regional University of the Northwest of Rio Grande do Sul, 
Street of Comércio 3000, Universitário, Ijuí/RS - Brazil

E-mail: andressaraqueldelima@gmail.com

Francine Lautenchleger

State University of Central-West - Street Presidente Zacarias, 875, Guarapuava/PR Brazil

E-mail: francinelautenchleger@hotmail.com

\begin{abstract}
Natiane Carolina Ferrari Basso
Agrarian Studies Department, Regional University of the Northwest of Rio Grande do Sul, Street of Comércio 3000, Universitário, Ijuí/RS - Brazil

E-mail: natianeferrari@gmail.com
\end{abstract}

\title{
Cláudia Vanessa Argenta
}

Agrarian Studies Department, Regional University of the Northwest of Rio Grande do Sul, Street of Comércio 3000, Universitário, Ijuí/RS - Brazil

E-mail: claudia_argenta@yahoo.com

\section{Julio Daronco Berlezi}

Agrarian Studies Department, Regional University of the Northwest of Rio Grande do Sul, Street of Comércio 3000, Universitário, Ijuí/RS - Brazil

E-mail: julio.berlezi28@hotmail.com

\section{Felipe Uhde Porazzi}

Agrarian Studies Department, Regional University of the Northwest of Rio Grande do Sul, Street of Comércio 3000, Universitário, Ijuí/RS - Brazil

E-mail: felipe.uhde@ hotmail.com

\section{Ester Mafalda Matter}

Agrarian Studies Department, Regional University of the Northwest of Rio Grande do Sul, Street of Comércio 3000, Universitário, Ijuí/RS - Brazil 
E-mail: estermafaldamatter@gmail.com

\title{
Leonardo Norbert
}

Agrarian Studies Department, Regional University of the Northwest of Rio Grande do Sul, Street of Comércio 3000, Universitário, Ijuí/RS - Brazil

E-mail: norbert.leonardo6@gmail.com

Received: Oct. 29, 2019 Accepted: Nov. 18, $2019 \quad$ Published: Nov. 26, 2019

doi:10.5296/jas.v8i2.15728

URL: https://doi.org/10.5296/jas.v8i2.15728

\begin{abstract}
The supply of glutamic acid-based biostimulants may represent an innovative technology to increase oat grain yield and quality. The objective of this study is to measure the effect of different biostimulants based on concentrations of glutamic acid and nutrients and their application on indicators of productivity and industrial and chemical quality of oat grains. The study was conducted in 2016 and 2017 in a randomized block design with four replications, considering 10 combinations of treatments for different application conditions and types of glutamic acid-based biostimulants, which were: 1. Control; 2. Zinplex (seed) + Biomol (grain filling); 3. Zinplex (seed) + Glutamin Extra (grain filling); 4. Zinplex (seed) + Biomol (thinning); 5. Glutamin Extra $\left(1^{\text {st }}\right.$ fungicide application) + Glutamin Extra $\left(2^{\text {nd }}\right.$ fungicide application); 6. Biomol ( $1^{\text {st }}$ fungicide application $)+$ Biomol $\left(2^{\text {nd }}\right.$ fungicide application); 7. Zinplex (seed) + Vorax (grain filling); 8. Vorax $\left(1^{\text {st }}\right.$ fungicide application $)+$ Vorax ( $2^{\text {nd }}$ fungicide application); 9. Biomol (thinning) + Vorax (grain filling) and 10. Biomol (thinning) + Glutamin Extra (grain filling). The foliar application of biostimulants with the presence of glutamic acid and nutrients may have positive effects on variables related to productivity and industrial and chemical quality of oat grains, however, depending on the agricultural year conditions. The application of Glutamin Extra in the 1st and 2nd fungicide application shows the best results in the vast majority of grain yield and quality variables, but the costs involving only biostimulants do not guarantee economic viability.
\end{abstract}

Keywords: Avena sativa, glutamic acid, nutrients, modeling, sustainability

\section{Introduction}

Oat is one of the most widely grown cereals in southern Brazil, representing a multi-purpose species (Hawerroth et al., 2015; Dornelles et al., 2018). Used in animal and human feed, it is classified as functional food by doctors and nutritionists (Hawerroth et al., 2013; Mantai et al., 2016a). Therefore, it has been increasingly used in the food industry, especially in the form of flakes and flour, combined with numerous products (Mantai et al., 2016b; Scremin et al., 2017). 
The expression of oat yield is associated with the genetic characteristics of each cultivar, the weather conditions during growing and the management technologies of the species (Brezolin et al., 2016; Romitti et al., 2016). Among management technologies, adequate nutrient supply is critical in ensuring grain quality yield (Mantai et al., 2015; Marolli et al., 2018). In this perspective, the sources of plant nutrients are obtained from the soil by the stored availability, animal droppings, the decomposition of crop residues and the use of formulated fertilizers, with the root canal being the main form of absorption (Pereira et al., 2013; Maluf et al., 2015).

During management, unfavorable environmental conditions are common, causing unavailability of absorption of the elements. Fertilizer supply under these conditions shows reduced efficiency with consequent loss of productivity, besides increased production costs and generation of environmental contamination (Silva et al., 2015; Marolli et al., 2018). In agriculture these restrictions usually occur when the air temperature is high and/or low soil moisture due to a long period without rainfall (Arenhardt et al., 2015; Henrichsen et al., 2018).

One possibility of improving the efficiency of nutrient utilization in agricultural crops is the application of biostimulants (Carvalho \& Zabot, 2012; Domingos et al., 2015). Biostimulants are a mixture of growth regulators isolated and / or combined with other compounds, such as amino acids, nutrients, vitamins and others, which seek to provide nutrition and help in overcoming stress (Castro \& Vieira, 2001; Kolling et al., 2016). These compounds modify protein expression acting on defense mechanisms, enzyme activation and plant nutrition and are generally provided considering the absorption route via leaf (Almeida et al., 2009; Olsen et al., 2016).

An important amino acid for cellular metabolism is L-glutamic acid, which has an expressive diversity of biological functions and represents the central precursor molecule of the other amino acids of plant metabolism and plays a fundamental role in the synthesis of chlorophyll on leaves (Forde \& Lea, 2007; Carvalho et al., 2013). From this perspective, the possibility of supplying biostimulants that have glutamic acid combined with nutrients in their composition may represent a technology capable of improving the absorption efficiency of the elements via leaf and withstanding environmental stresses, enabling improvement in the expression of yield and quality indicators of oat grains, under favorable as well as unfavorable conditions of growing.

The objective of this study is to measure the effect of different biostimulants based on concentrations of glutamic acid and nutrients and their application on indicators of productivity and industrial and chemical quality of oat grains.

\section{Materials and Methods}

\subsection{Crop Area Description}

The study was conducted in the agricultural years 2016 and 2017 in the municipality of

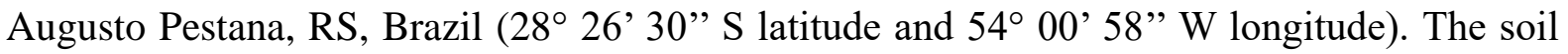
of the experimental area is classified as typical dystroferric Red Latosol (Oxisol) and the 
climate of the region by Köppen classification of Cfa type, with hot summer without dry season. For the study, ten days before sowing soil analysis was performed and the following chemical characteristics of the site were identified: $\mathrm{pH}=6.2 ; \mathrm{P}=33.9 \mathrm{mg} \mathrm{dm}^{-3} ; \mathrm{K}=200 \mathrm{mg}$

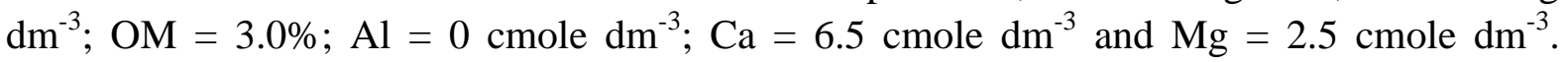
Regardless of crop year, sowing was between the first and second fortnight of May, in residual cover of low $\mathrm{C} / \mathrm{N}$ ratio (soy / oat system).

\subsection{Experimental Design}

In the implementation a seeder-fertilizer was used in the composition of the plot with 5 rows of $5 \mathrm{~m}$ in length and row spacing of $0.20 \mathrm{~m}$, forming the experimental unit of $5 \mathrm{~m}^{2}$. At sowing, 30 and $20 \mathrm{~kg} \mathrm{ha}^{-1}$ of $\mathrm{P}_{2} \mathrm{O}_{5}$ and $\mathrm{K}_{2} \mathrm{O}$ were applied, respectively, based on soil $\mathrm{P}$ and $\mathrm{K}$ contents, and nitrogen at sowing with $10 \mathrm{~kg} \mathrm{ha}^{-1}$ and the $40 \mathrm{~kg} \mathrm{ha}^{-1}$ remaining for topdressing, applied at the phenological stage of the expanded fourth leaf to meet the expected grain yield expectation of $3 \mathrm{t} \mathrm{ha}^{-1}$, with nitrogen available as urea. The seeds were submitted to germination and vigor tests in the laboratory to correct the desired density of 400 viable seeds $\mathrm{m}^{2}$. During the study, tebuconazole fungicide was applied at a dosage of $0.75 \mathrm{~L} \mathrm{ha}^{-1}$. Weed control was carried out with metsulfuron-methyl herbicide at a dose of $4 \mathrm{~g} \mathrm{ha}^{-1}$. The cultivar used was URS Tarimba, which has an early cycle and a large size.

The experimental design was a randomized complete block with four replications with ten treatments representing different concentrations of biostimulants in different application times, which were: 1. Control; 2. Zinplex (seed) + Biomol (grain filling); 3. Zinplex (seed) + Glutamin Extra (grain filling); 4. Zinplex (seed) + Biomol (thinning); 5. Glutamin Extra (1 ${ }^{\text {st }}$ fungicide application $)+$ Glutamin Extra ( $2^{\text {nd }}$ fungicide application); 6. Biomol ( $1^{\text {st }}$ fungicide application) + Biomol ( $2^{\text {nd }}$ fungicide application); 7. Zinplex (seed) + Vorax (grain filling); 8 . Vorax $\left(1^{\text {st }}\right.$ fungicide application $)+$ Vorax ( $2^{\text {nd }}$ fungicide application $) ; 9$. Biomol (thinning) + Vorax (grain filling) and 10. Biomol (thinning) + Glutamin Extra (grain filling). Table 1 describes the chemical composition of the biostimulants used in the study and their concentrations of glutamic acid. It is noteworthy that the first fungicide application was performed in the phase near the panicle emission (80 days after emergence) and at the beginning of grain filling (100 days after emergence). 


\section{Macrothink}

Table 1. Description of chemical composition of biostimulants tested in oat

\begin{tabular}{|c|c|c|c|}
\hline Commercial name & Chemical composition & $\mathrm{g} \mathrm{L}^{-1}$ & $(\%)$ \\
\hline \multirow{2}{*}{ Zinplex } & $\mathrm{Zn}$ & 79,8 & 7,0 \\
\hline & Acidifying agent & - & 1,5 \\
\hline \multirow{11}{*}{ Glutamin Extra } & $\mathrm{N}$ & 98,4 & 8,0 \\
\hline & $\mathrm{P}_{2} \mathrm{O}_{5}$ & 61,5 & 5,0 \\
\hline & $\mathrm{K}_{2} \mathrm{O}$ & 12,3 & 1,0 \\
\hline & $\mathrm{Mg}$ & 6,15 & 0,5 \\
\hline & $\mathrm{S}$ & 12,3 & 1,0 \\
\hline & $\mathrm{B}$ & 6,15 & 0,5 \\
\hline & $\mathrm{Mn}$ & 18,45 & 1,5 \\
\hline & Mo & 0,12 & 0,0 \\
\hline & $\mathrm{Zn}$ & 6,15 & 0,5 \\
\hline & Total Organic Carbon & 67,7 & 5,5 \\
\hline & L-Glutamic Acid & - & 3,0 \\
\hline \multirow{4}{*}{ BioMol } & $\mathrm{Mn}$ & 1,3 & 0,1 \\
\hline & Mo & 91 & 7,0 \\
\hline & Acidifying agent & - & 8,0 \\
\hline & L-Glutamic Acid & - & 10,0 \\
\hline \multirow{5}{*}{ Vorax } & $\mathrm{N}$ & 50 & 4,0 \\
\hline & Total Organic Carbon & 225 & 18,0 \\
\hline & Seaweed Extract & - & 1,0 \\
\hline & Amino Acid Glycine Betaine & - & 1,0 \\
\hline & L-Glutamic Acid & - & 25,0 \\
\hline
\end{tabular}

Source: Microquímica, 2017

\subsection{Indicators of Yield, Industrial Quality and Chemical Composition of Grains}

In the study the indicators of yield, industrial quality and chemical composition of oat grains were evaluated. For the yield indicators by the inflorescence analysis, 10 random panicles were collected in each experimental plot to measure the following variables: Panicle Length (PL, cm) using a ruler; Panicle Mass (PM, g) and Panicle Grain Mass (PGM, g) with precision balance; Number of Spikelets per Panicle (NPP, No.) and Number of Grains in Panicle (NGP, No.) by count; Panicle Harvest Index (PHI, $\mathrm{g} \mathrm{g}^{-1}$ ) by dividing panicle grain mass by panicle mass. For yield indicators by yield analysis per area, two experiments were conducted, one to quantify the biomass yield rate and the other to estimate grain yield. Biomass yield (BY, $\mathrm{kg} \mathrm{ha}^{-1}$ ) was obtained by cutting the three central lines of each plot close to the soil at the physiological maturity stage. The biomass samples were directed to a forced 
air oven at $65{ }^{\circ} \mathrm{C}$ until constant weight and converted to $\mathrm{kg} \mathrm{ha}^{-1}$. Grain Yield (GY, kg ha ${ }^{-1}$ ) was obtained by cutting the three central lines of each plot at the harvest maturity stage, grain moisture around $22 \%$. After the plants were tracked with a stationary harvester and the grains directed to the laboratory for moisture correction to $13 \%$. Straw yield ( $\mathrm{SY}, \mathrm{kg} \mathrm{ha}^{-1}$ ) was obtained by subtracting grain yield from biomass yield and Harvest Index (HI, $\mathrm{kg} \mathrm{ha}^{-1}$ ) from the ratio of grain yield to biomass yield. For industrial quality indicators, the following variables were measured: Thousand Grain Mass (TGM, g) determined by counting 250 grains and weighing on a precision balance, then multiplied by four; Hectoliter mass ( $\mathrm{HM}, \mathrm{kg} \mathrm{hl}^{-1}$ ) obtained by the grain mass from a known cube of $250 \mathrm{~cm}^{3}$ and converted to $\mathrm{kg} \mathrm{hl}^{-1}$; Number of Grains larger than two millimeters (NG>2 mm, n) by counting a hundred grains, which are placed in a $2 \mathrm{~mm}$ mesh sieve and counted those above that size; Husking Index (HUI, g $\mathrm{kg}^{-1}$ ) obtained by the ratio between the caryopsis (CM, g) and grain mass (GM, g) from 50 grains larger than $2 \mathrm{~mm}$; Industrial Yield (IY, $\mathrm{kg} \mathrm{ha}^{-1}$ ) by the product of grain yield with the number of grains larger than $2 \mathrm{~mm}$ divided by 100 and the husking index (IY = GY x (NG) $2 \mathrm{~mm} / 100) \mathrm{x}$ HUI). In the indicators of chemical quality of oat grains, there were evaluated: Starch (ST, g kg${ }^{-1}$ ), Crude Protein (CP, $\mathrm{g} \mathrm{kg}^{-1}$ ), Total Fiber (TF, $\mathrm{g} \mathrm{kg}^{-1}$ ), Neutral Detergent Fiber (NDF, $\mathrm{g} \mathrm{kg}^{-1}$ ), Ash (ASH g kg ${ }^{-1}$ ) and Energy (EN, MJ kg-1) by proximal NIRs infrared spectrophotometry by Perten, Diode Array DA 7200. The study also evaluated the weather conditions during the growing cycle, evaluating the air temperature $\left({ }^{\circ} \mathrm{C}\right)$ and rainfall $(\mathrm{mm})$ by the Total Automatic Station installed 500 meters from the experiment.

An analysis of variance was performed to detect differences between treatment levels on the expression of yield, industrial and chemical quality indicators of oat grains. Afterwards, the comparison test of means by the Scott and Knott model at 5\% probability of error and multivariate statistics was performed to analyze the relative contribution of the effects of biostimulants on the variable group of each indicator. In all analyzes, the computer program Genes (Cruz, 2006) was used.

\section{Results and Discussion}

In Figure 1, about the weather conditions in the oat growing cycle, 2016 indicated a total rainfall of $973 \mathrm{~mm}$, similar to the historical average of the last 20 years $(909 \mathrm{~mm}$ ) and with adequate rainfall distribution throughout the cycle. Nitrogen fertilization conditions were adequate with soil moisture due to previous rainfall. The maximum temperature remained milder in the growing season, which may have contributed to the increase of tillering expression, component of greater contribution on the elaboration of grain yield by area. These conditions provided grain yield that characterizes 2016 as favorable (FY) for oat growing. In 2017 (Figure 1), rainfall was irregularly distributed, with large rainfall at the end of the crop cycle, causing unfavorable harvest conditions. In addition, the nitrogen supply was under water restriction due to the long period of lack of rainfall since the implementation. The maximum temperatures were raised during almost the whole growing cycle with tendency of higher energy expenditure due to the higher respiration rate, therefore, the low yield obtained characterizes the year 2017 as unfavorable year (UY) to the crop. 


\section{Macrothink}

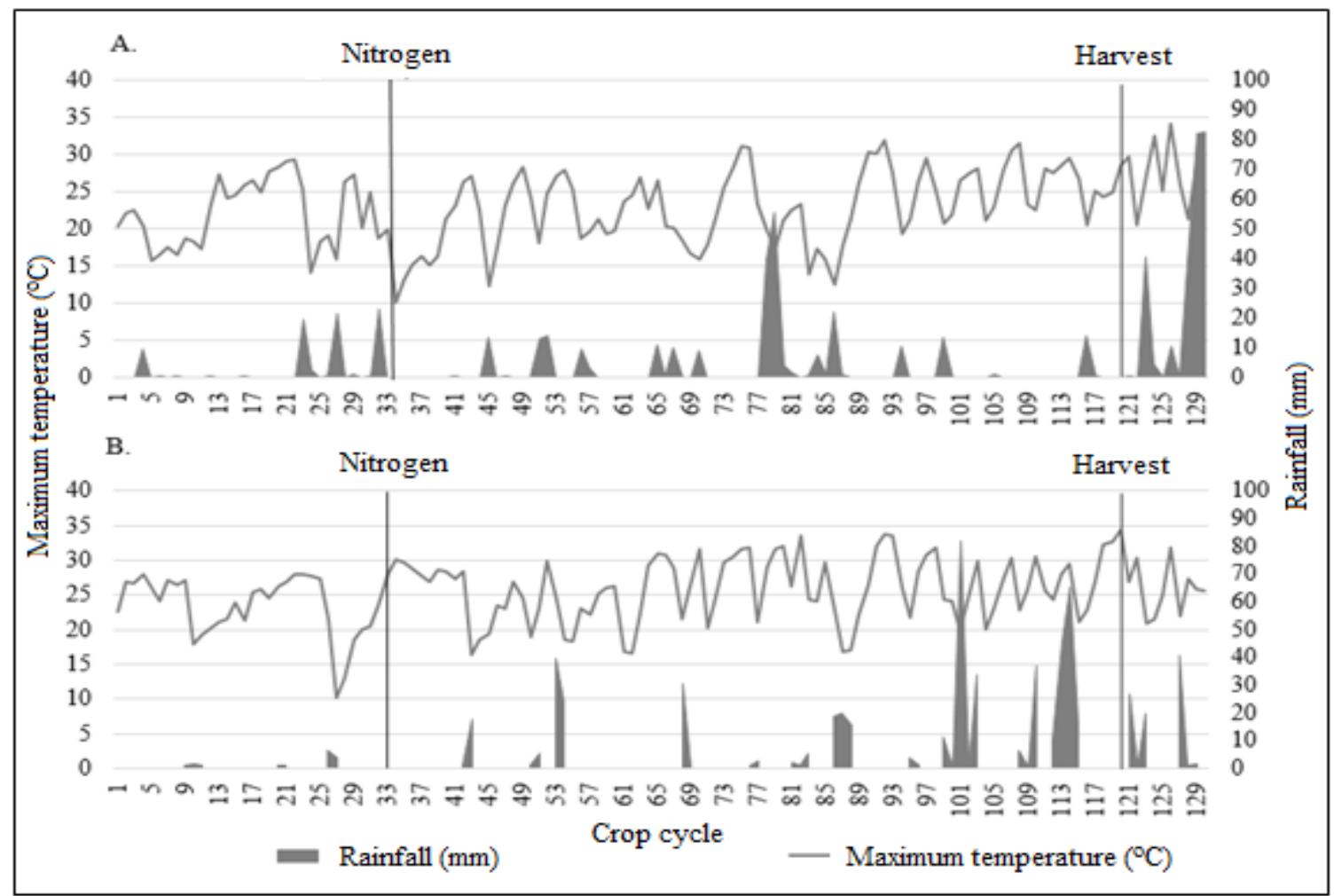

Figure 1. Rainfall and maximum temperature in the oat cycle, $A=$ Year 2016 and $B=$ Year 2017

Rainfall stands out as one of the main factors responsible for variations in agricultural yield. Prior knowledge of precipitation conditions may indicate management methods that ensure the success of the activity (Arf et al., 2012; Arenhardt et al., 2015). In winter cereals, however, rainfall without large volumes, which favors adequate soil moisture and well distributed throughout the crop cycle, characterizes a favorable environment for nitrogen management and greater expression of yield (Castro et al., 2012; Souza et al., 2013). In addition to precipitation, air temperature also acts strongly on nitrogen utilization dynamics and productivity expression. Temperature acts as a catalyst for biological processes, which is why plants require a minimum and maximum temperature for normal physiological activities (Tonin et al., 2014; Marolli et al., 2017). High temperatures promote reduced productivity and reduced biomass accumulation due to lower net photosynthesis obtained due to increased respiration rate, reducing nitrogen utilization efficiency (Arenhardt et al., 2015; Mantai et al., 2016b). Nitrogen supply followed by excessive rainfall leads to leachate losses, and when supplied with low soil moisture and high air temperature, cause volatilization losses. Therefore, reducing productivity, generating environmental contamination and collaborating on events related to global warming (Mandal et al., 2016; Arenhardt et al., 2017).

In the analysis of variance (not shown), in general, the effect of biostimulant treatments on oat grain yield and quality indicators were dependent on the condition of the year of growing. Therefore, the treatment effects on the indicators follow with the presentation of results by agricultural year condition. In Table 2, averages in 2017, the expression of grain yield and harvest index were not altered by the conditions of use of biostimulants. However, the 
biological and straw yields were modified, with better response in the use of treatments 2 (Zinplex in seed + Biomol in grain filling), 5 (Glutamin Extra along with $1^{\text {st }}$ and $2^{\text {nd }}$ fungicide application), 6 (Biomol along with the 1st and 2nd fungicide application), 8 (Vorax along with the 1 st and 2nd fungicide application) and 9 (Biomol in tillering + Vorax in grain filling).

Table 2. Analysis of average of oat yield indicators by conditions of biostimulants use

\begin{tabular}{crrrr}
\hline Treatment & $\begin{array}{c}\text { GY } \\
\left(\mathrm{kg} \mathrm{ha}^{-1}\right)\end{array}$ & $\begin{array}{c}\text { BY } \\
\left(\mathrm{kg} \mathrm{ha}^{-1}\right)\end{array}$ & $\begin{array}{c}\text { SY } \\
\left(\mathrm{kg} \mathrm{ha}^{-1}\right)\end{array}$ & $\begin{array}{c}\text { HI } \\
\left(\mathrm{kg} \mathrm{kg}^{-1}\right)\end{array}$ \\
\hline & & \multicolumn{2}{c}{$2017(\mathrm{UY})$} \\
1 & $949 \mathrm{a}$ & $6824 \mathrm{~b}$ & $5875 \mathrm{~b}$ & $0,14 \mathrm{a}$ \\
2 & $1041 \mathrm{a}$ & $7851 \mathrm{a}$ & $6759 \mathrm{a}$ & $0,14 \mathrm{a}$ \\
3 & $1057 \mathrm{a}$ & $7041 \mathrm{~b}$ & $5984 \mathrm{~b}$ & $0,15 \mathrm{a}$ \\
4 & $989 \mathrm{a}$ & $7171 \mathrm{~b}$ & $6182 \mathrm{~b}$ & $0,13 \mathrm{a}$ \\
5 & $1139 \mathrm{a}$ & $7781 \mathrm{a}$ & $6642 \mathrm{a}$ & $0,14 \mathrm{a}$ \\
6 & $1118 \mathrm{a}$ & $8096 \mathrm{a}$ & $6978 \mathrm{a}$ & $0,14 \mathrm{a}$ \\
7 & $1133 \mathrm{a}$ & $6765 \mathrm{~b}$ & $5731 \mathrm{~b}$ & $0,15 \mathrm{a}$ \\
8 & $1070 \mathrm{a}$ & $7765 \mathrm{a}$ & $6695 \mathrm{a}$ & $0,13 \mathrm{a}$ \\
9 & $946 \mathrm{a}$ & $7664 \mathrm{a}$ & $6717 \mathrm{a}$ & $0,12 \mathrm{a}$ \\
10 & $990 \mathrm{a}$ & $7275 \mathrm{~b}$ & $6284 \mathrm{~b}$ & $0,13 \mathrm{a}$ \\
\hline & & & $2016(\mathrm{FY})$ & \\
2 & $2408 \mathrm{~b}$ & $8406 \mathrm{~b}$ & $5998 \mathrm{c}$ & $0,28 \mathrm{a}$ \\
3 & $2398 \mathrm{~b}$ & $8475 \mathrm{~b}$ & $6077 \mathrm{c}$ & $0,28 \mathrm{a}$ \\
4 & $2372 \mathrm{~b}$ & $8023 \mathrm{c}$ & $5651 \mathrm{~d}$ & $0,29 \mathrm{a}$ \\
5 & $2196 \mathrm{c}$ & $9405 \mathrm{a}$ & $7209 \mathrm{a}$ & $0,23 \mathrm{c}$ \\
6 & $2701 \mathrm{a}$ & $9410 \mathrm{a}$ & $6621 \mathrm{~b}$ & $0,29 \mathrm{a}$ \\
7 & $2619 \mathrm{a}$ & $8907 \mathrm{a}$ & $6288 \mathrm{c}$ & $0,29 \mathrm{a}$ \\
8 & $2413 \mathrm{~b}$ & $8004 \mathrm{c}$ & $5591 \mathrm{~d}$ & $0,30 \mathrm{a}$ \\
9 & $2633 \mathrm{a}$ & $8650 \mathrm{~b}$ & $6016 \mathrm{c}$ & $0,30 \mathrm{a}$ \\
10 & $2403 \mathrm{~b}$ & $9284 \mathrm{a}$ & $6880 \mathrm{a}$ & $0,26 \mathrm{~b}$ \\
\hline & $2816 \mathrm{a}$ & $9355 \mathrm{a}$ & $6539 \mathrm{~b}$ & $0,30 \mathrm{a}$ \\
\hline
\end{tabular}

$\mathrm{GY}=$ grain yield $; \mathrm{BY}=$ biomass yield $; \mathrm{SY}=$ straw yield $; \mathrm{HI}=$ harvest index; $\mathrm{T} 1=$ Control; $\mathrm{T} 2$ = Zinplex (seed) + Biomol (grain filling); T3 = Zinplex (seed) + Glutamin Extra (grain filling); T4 = Zinplex (seed) + Biomol (thinning); T5 = Glutamin Extra along with the $1^{\text {st }}$ and 2nd fungicide application; T6 = Biomol along with the 1st and 2nd fungicide application; T7 $=$ Zinplex (seed) + Vorax (grain filling); $\mathrm{T} 8=$ Vorax along with the 1 st and 2nd fungicide application; $\mathrm{T} 9=$ Biomol (thinning) + Vorax (grain filling); $\mathrm{T} 10=$ Biomol (thinning) + Glutamin Extra (grain filling).

In general, the supply of biostimulants from Glutamin Extra, Biomol and Vorax products show better results in foliar application with the first and second fungicide application. In 2016, the highest yield of biomass and grains was obtained with treatments 5 (Glutamin Extra along with the 1st and 2nd fungicide application), 6 (Biomol along with the 1st and 2nd 
fungicide application) and 10 (Biomol in the tillering + Glutamin Extra in Grain Filling). Under these conditions the harvest indexes were also higher, showing that the increase of the grain elaboration reduced the leaf and stem expression (straw yield). The results also indicated the need for two application times, either in the first and second application of fungicide with Glutamin Extra and Biomol or the combined action of Biomol with Glutamin in the tillering and grain filling, respectively.

In Table 3, in 2017, the industrial quality indicators of oat grains highlighted treatments 5 (Glutamin Extra along with the 1st and $2^{\text {nd }}$ fungicide application), 6 (Biomol along with the $1^{\text {st }}$ and $2^{\text {nd }}$ fungicide application) and 7 (Zinplex on the seed + Vorax in grain filling) for the most promising results in the expression of oat grain industrial yield. Although the other variables showed no change, the absolute values obtained indicated more expressive mean values, a condition that may have driven a cumulative effect on the expression of industrial grain yield.

Table 3. Analysis of averages of oat industrial quality indicators by conditions of biostimulants use

\begin{tabular}{crrrrrr}
\hline Treatment & $\begin{array}{c}\text { GY } \\
\left(\mathrm{kg} \mathrm{ha}^{-1}\right)\end{array}$ & $\begin{array}{c}\text { TGM } \\
(\mathrm{g})\end{array}$ & $\begin{array}{c}\mathrm{HM} \\
\left(\mathrm{kg} \mathrm{hl}^{-1}\right)\end{array}$ & $\begin{array}{c}\text { NG>2 } \\
(\mathrm{n})\end{array}$ & $\begin{array}{c}\text { HUI } \\
\left(\mathrm{g} \mathrm{kg}^{-1}\right)\end{array}$ & $\begin{array}{c}\text { IY } \\
\left(\mathrm{kg} \mathrm{ha}^{-1}\right)\end{array}$ \\
\hline 1 & & & $2017(\mathrm{UY})$ & & \\
2 & $949 \mathrm{a}$ & $28,1 \mathrm{a}$ & $50 \mathrm{a}$ & $76 \mathrm{a}$ & $0,69 \mathrm{~b}$ & $498 \mathrm{c}$ \\
3 & $1041 \mathrm{a}$ & $30,1 \mathrm{a}$ & $49 \mathrm{a}$ & $79 \mathrm{a}$ & $0,71 \mathrm{~b}$ & $584 \mathrm{~b}$ \\
4 & $1057 \mathrm{a}$ & $30,5 \mathrm{a}$ & $50 \mathrm{a}$ & $76 \mathrm{a}$ & $0,75 \mathrm{a}$ & $602 \mathrm{~b}$ \\
5 & $989 \mathrm{a}$ & $29,8 \mathrm{a}$ & $49 \mathrm{a}$ & $76 \mathrm{a}$ & $0,77 \mathrm{a}$ & $579 \mathrm{~b}$ \\
6 & $1139 \mathrm{a}$ & $28,6 \mathrm{a}$ & $52 \mathrm{a}$ & $79 \mathrm{a}$ & $0,76 \mathrm{a}$ & $684 \mathrm{a}$ \\
7 & $1118 \mathrm{a}$ & $28,1 \mathrm{a}$ & $52 \mathrm{a}$ & $81 \mathrm{a}$ & $0,74 \mathrm{a}$ & $670 \mathrm{a}$ \\
8 & $1133 \mathrm{a}$ & $28,8 \mathrm{a}$ & $50 \mathrm{a}$ & $79 \mathrm{a}$ & $0,78 \mathrm{a}$ & $698 \mathrm{a}$ \\
9 & $1070 \mathrm{a}$ & $28,5 \mathrm{a}$ & $51 \mathrm{a}$ & $74 \mathrm{a}$ & $0,76 \mathrm{a}$ & $602 \mathrm{~b}$ \\
10 & $946 \mathrm{a}$ & $29,6 \mathrm{a}$ & $51 \mathrm{a}$ & $78 \mathrm{a}$ & $0,76 \mathrm{a}$ & $561 \mathrm{~b}$ \\
\hline & $990 \mathrm{a}$ & $29,8 \mathrm{a}$ & $50 \mathrm{a}$ & $80 \mathrm{a}$ & $0,74 \mathrm{a}$ & $586 \mathrm{~b}$ \\
\hline & & & & $2016(\mathrm{FY})$ & & \\
3 & $2408 \mathrm{~b}$ & $25,3 \mathrm{a}$ & $47 \mathrm{a}$ & $65 \mathrm{~b}$ & $0,70 \mathrm{a}$ & $1096 \mathrm{~b}$ \\
4 & $2398 \mathrm{~b}$ & $24,7 \mathrm{a}$ & $44 \mathrm{a}$ & $63 \mathrm{~b}$ & $0,61 \mathrm{~b}$ & $921 \mathrm{~b}$ \\
5 & $2372 \mathrm{~b}$ & $23,3 \mathrm{a}$ & $41 \mathrm{a}$ & $70 \mathrm{~b}$ & $0,69 \mathrm{a}$ & $1146 \mathrm{~b}$ \\
6 & $2196 \mathrm{c}$ & $22,5 \mathrm{a}$ & $42 \mathrm{a}$ & $70 \mathrm{~b}$ & $0,71 \mathrm{a}$ & $1091 \mathrm{~b}$ \\
7 & $2701 \mathrm{a}$ & $25,3 \mathrm{a}$ & $45 \mathrm{a}$ & $78 \mathrm{a}$ & $0,69 \mathrm{a}$ & $1454 \mathrm{a}$ \\
8 & $2619 \mathrm{a}$ & $22,8 \mathrm{a}$ & $45 \mathrm{a}$ & $59 \mathrm{~b}$ & $0,73 \mathrm{a}$ & $1128 \mathrm{~b}$ \\
9 & $2413 \mathrm{~b}$ & $22,8 \mathrm{a}$ & $43 \mathrm{a}$ & $78 \mathrm{a}$ & $0,73 \mathrm{a}$ & $1374 \mathrm{a}$ \\
10 & $2633 \mathrm{a}$ & $25,1 \mathrm{a}$ & $45 \mathrm{a}$ & $70 \mathrm{~b}$ & $0,73 \mathrm{a}$ & $1345 \mathrm{a}$ \\
& $2403 \mathrm{~b}$ & $24,3 \mathrm{a}$ & $45 \mathrm{a}$ & $67 \mathrm{~b}$ & $0,69 \mathrm{a}$ & $1111 \mathrm{~b}$ \\
& $2816 \mathrm{a}$ & $23,7 \mathrm{a}$ & $42 \mathrm{a}$ & $65 \mathrm{~b}$ & $0,68 \mathrm{a}$ & $1245 \mathrm{~b}$ \\
\hline
\end{tabular}

$\mathrm{GY}=$ grain yield $; \mathrm{TGM}=$ housand grain mass; $\mathrm{HM}=$ hectolitre mass; $\mathrm{NG}>2 \mathrm{~mm}=$ number of grains larger than two millimeters; HUI = husking index; IY = industrial yield; T1 = Control; T2 = Zinplex (seed) + Biomol (grain filling); T3 = Zinplex (seed) + Glutamin Extra (grain filling); T4 = Zinplex (seed) + Biomol (thinning); T5 = Glutamin Extra along with the $1^{\text {st }}$ and $2^{\text {nd }}$ fungicide application; T6 = Biomol along with the $1^{\text {st }}$ and $2^{\text {nd }}$ fungicide application; $\mathrm{T} 7$ = Zinplex (seed) + Vorax (grain filling); $\mathrm{T} 8=$ Vorax along with the $1^{\text {st }}$ and $2^{\text {nd }}$ fungicide application; T9 = Biomol (thinning) + Vorax (grain filling); T10 = Biomol (thinning) + Glutamin Extra (grain filling). 
In 2016 (Table 3), the expression of grain yield along with the number of grains greater than $2 \mathrm{~mm}$ and husking index was increased by treatments 5 (Glutamin Extra along with the 1st and 2nd fungicide application), promoting the expression of the highest industrial grain yield. Although grain yield with treatment 7 (Zinplex + Vorax in grain filling) was statistically lower, the other components of industrial quality were increased, especially the number of grains greater than $2 \mathrm{~mm}$, also allowing to express the higher industrial yield. It is noteworthy that also treatment 8 (Vorax along with the 1st and 2nd fungicide application) indicated higher industrial yield, mainly due to the contribution of higher grain yield. In general, treatment 5 (Glutamin Extra along with the 1st and 2nd fungicide application) was the only one that showed the most expressive results considering all the analyzed variables and encouraging the application of biostimulant in two applications with the control of leaf diseases.

In Table 4, of the variables of the chemical quality of oat grains, in 2017 no significant differences were observed by the use of biostimulants.

Table 4. Analysis of averages of oat chemical quality indicators by conditions of biostimulants use

\begin{tabular}{ccccccc}
\hline Treatment & $\begin{array}{c}\text { ST } \\
\left(\mathrm{g} \mathrm{kg}^{-1}\right)\end{array}$ & $\begin{array}{c}\mathrm{TP} \\
(\mathrm{g} \mathrm{kg})\end{array}$ & $\begin{array}{c}\mathrm{TF} \\
\left(\mathrm{g} \mathrm{kg}^{-1}\right)\end{array}$ & $\begin{array}{c}\mathrm{NDF} \\
\left(\mathrm{g} \mathrm{kg}^{-1}\right)\end{array}$ & $\begin{array}{c}\mathrm{ASH} \\
\left(\mathrm{g} \mathrm{kg}^{-1}\right)\end{array}$ & $\begin{array}{c}\mathrm{EN} \\
\left(\mathrm{MJ} \mathrm{kg}^{-1}\right)\end{array}$ \\
\hline 1 & $421 \mathrm{a}$ & $116 \mathrm{a}$ & $\begin{array}{c}123 \mathrm{a} \\
(\mathrm{UY})\end{array}$ & $334 \mathrm{a}$ & $32,0 \mathrm{a}$ & $11,6 \mathrm{a}$ \\
2 & $427 \mathrm{a}$ & $116 \mathrm{a}$ & $122 \mathrm{a}$ & $332 \mathrm{a}$ & $31,5 \mathrm{a}$ & $11,8 \mathrm{a}$ \\
3 & $434 \mathrm{a}$ & $121 \mathrm{a}$ & $123 \mathrm{a}$ & $333 \mathrm{a}$ & $30,0 \mathrm{a}$ & $11,8 \mathrm{a}$ \\
4 & $427 \mathrm{a}$ & $117 \mathrm{a}$ & $123 \mathrm{a}$ & $338 \mathrm{a}$ & $32,2 \mathrm{a}$ & $11,9 \mathrm{a}$ \\
5 & $420 \mathrm{a}$ & $116 \mathrm{a}$ & $120 \mathrm{a}$ & $332 \mathrm{a}$ & $31,0 \mathrm{a}$ & $11,6 \mathrm{a}$ \\
6 & $424 \mathrm{a}$ & $117 \mathrm{a}$ & $125 \mathrm{a}$ & $339 \mathrm{a}$ & $31,7 \mathrm{a}$ & $11,9 \mathrm{a}$ \\
7 & $417 \mathrm{a}$ & $116 \mathrm{a}$ & $120 \mathrm{a}$ & $327 \mathrm{a}$ & $29,7 \mathrm{a}$ & $11,9 \mathrm{a}$ \\
8 & $415 \mathrm{a}$ & $116 \mathrm{a}$ & $120 \mathrm{a}$ & $330 \mathrm{a}$ & $30,2 \mathrm{a}$ & $11,9 \mathrm{a}$ \\
9 & $414 \mathrm{a}$ & $116 \mathrm{a}$ & $121 \mathrm{a}$ & $341 \mathrm{a}$ & $29,2 \mathrm{a}$ & $11,8 \mathrm{a}$ \\
10 & $417 \mathrm{a}$ & $116 \mathrm{a}$ & $123 \mathrm{a}$ & $342 \mathrm{a}$ & $31,0 \mathrm{a}$ & $11,8 \mathrm{a}$ \\
\hline & & & & $2016(F Y)$ & & \\
1 & $445 \mathrm{~b}$ & $118 \mathrm{~b}$ & $125 \mathrm{~b}$ & $304 \mathrm{c}$ & $36,2 \mathrm{a}$ & $12,1 \mathrm{a}$ \\
2 & $440 \mathrm{~b}$ & $124 \mathrm{a}$ & $126 \mathrm{~b}$ & $315 \mathrm{~b}$ & $34,2 \mathrm{a}$ & $11,9 \mathrm{a}$ \\
3 & $458 \mathrm{a}$ & $118 \mathrm{~b}$ & $130 \mathrm{~b}$ & $317 \mathrm{~b}$ & $40,7 \mathrm{a}$ & $11,9 \mathrm{a}$ \\
4 & $443 \mathrm{~b}$ & $116 \mathrm{~b}$ & $127 \mathrm{~b}$ & $316 \mathrm{~b}$ & $35,7 \mathrm{a}$ & $11,9 \mathrm{a}$ \\
5 & $462 \mathrm{a}$ & $115 \mathrm{~b}$ & $135 \mathrm{a}$ & $324 \mathrm{a}$ & $37,0 \mathrm{a}$ & $11,8 \mathrm{a}$ \\
6 & $443 \mathrm{~b}$ & $121 \mathrm{a}$ & $125 \mathrm{~b}$ & $313 \mathrm{~b}$ & $37,0 \mathrm{a}$ & $12,0 \mathrm{a}$ \\
7 & $456 \mathrm{a}$ & $110 \mathrm{c}$ & $127 \mathrm{~b}$ & $300 \mathrm{c}$ & $38,2 \mathrm{a}$ & $12,0 \mathrm{a}$ \\
8 & $445 \mathrm{~b}$ & $115 \mathrm{~b}$ & $136 \mathrm{a}$ & $330 \mathrm{a}$ & $36,0 \mathrm{a}$ & $11,8 \mathrm{a}$ \\
9 & $442 \mathrm{~b}$ & $115 \mathrm{~b}$ & $124 \mathrm{~b}$ & $309 \mathrm{~b}$ & $35,0 \mathrm{a}$ & $12,0 \mathrm{a}$ \\
10 & $461 \mathrm{a}$ & $115 \mathrm{~b}$ & $136 \mathrm{a}$ & $326 \mathrm{a}$ & $36,7 \mathrm{a}$ & $11,8 \mathrm{a}$ \\
\hline
\end{tabular}

$\mathrm{ST}=$ starch $; \mathrm{TP}=$ total protein $; \mathrm{TF}=$ total fiber; $\mathrm{NDF}=$ neutral detergent fiber; $\mathrm{ASH}=\mathrm{ash} ;$ $\mathrm{EN}=$ energy; $\mathrm{T} 1$ = Control; T2 = Zinplex (seed) + Biomol (grain filling); T3 = Zinplex (seed) + Glutamin Extra (grain filling); T4 = Zinplex (seed) + Biomol (thinning); T5 = Glutamin Extra along with the $1^{\text {st }}$ and $2^{\text {nd }}$ fungicide application; T6 = Biomol along with the $1^{\text {st }}$ and $2^{\text {nd }}$ fungicide application; T7 = Zinplex (seed) + Vorax (grain filling); T8 = Vorax along with the $1^{\text {st }}$ and $2^{\text {nd }}$ fungicide application; T9 $=$ Biomol (thinning) + Vorax (grain filling); T10 = Biomol (thinning) + Glutamin Extra (grain filling). 
In 2016 (Table 4), treatment 5 (Glutamin Extra along with the 1st and 2nd fungicide application) showed greater expression on all variables, except for total protein. This condition was also observed in treatment 10 (Biomol in the thinning + Glutamin Extra in the grain filling). It is noteworthy that although these biostimulants reduce the protein content, promote elevation of the total fiber, a molecule of great interest linked to the nutraceutical properties of this species, especially in cholesterol reduction. In general, although statistical differences have been detected, the existing variations are minimal, do not bring major changes on the chemical quality of grains.

Table 5 presents the results of multivariate statistics by relative contribution analysis seeking to understand the degree of contribution of the use of biostimulants in the alteration of the variables of yield and industrial and chemical quality indicators of oat grains. In this perspective, considering the yield indicators, the greatest action of biostimulants is on the expression of straw yield, regardless of the favorable and unfavorable year conditions for oat growing. In an unfavorable year the modification by the use of biostimulants by straw is increased, however, in a favorable year, a greater contribution to the biomass and grain yield is shown.

Table 5. Relative contribution analysis on oat yield, inflorescence, industrial and chemical indicators by the conditions of biostimulants use

\begin{tabular}{|c|c|c|c|c|}
\hline \multirow{2}{*}{ Variables } & \multicolumn{2}{|c|}{ 2017(UY) } & \multicolumn{2}{|c|}{$2016(\mathrm{FY})$} \\
\hline & S.j & S.j(\%) & S.j & S.j(\%) \\
\hline & \multicolumn{4}{|c|}{ Yield indicators } \\
\hline PG $\left(\mathrm{kg} \mathrm{ha}^{-1}\right)$ & 1,85 & 1,05 & 8898,76 & 12,96 \\
\hline PB $\left(\mathrm{kg} \mathrm{ha}^{-1}\right)$ & 0,01 & 0,01 & 25748,01 & 37,52 \\
\hline $\mathrm{PP}\left(\mathrm{kg} \mathrm{ha}^{-1}\right)$ & 105,76 & 60,14 & 33704,59 & 49,11 \\
\hline IC $\left(\mathrm{kg} \mathrm{ha}^{-1}\right)$ & 68,23 & 38,80 & 265,62 & 0,38 \\
\hline \multicolumn{5}{|c|}{ Industrial Quality Indicators } \\
\hline $\mathrm{PG}\left(\mathrm{kg} \mathrm{ha}^{-1}\right)$ & 516,16 & 18,85 & 1298,92 & 47,71 \\
\hline$M M G(g)$ & 104,76 & 3,81 & 1,43 & 0,10 \\
\hline $\mathrm{MH}\left(\mathrm{kg} \mathrm{ha}^{-1}\right)$ & 137,01 & 5,00 & 169,43 & 6,22 \\
\hline $\mathrm{NG}>2 \mathrm{~mm}(\mathrm{n})$ & 167,32 & 6,11 & 214,2 & 7,86 \\
\hline ID $\left(\mathrm{g} \mathrm{kg}^{-1}\right)$ & 787,8 & 28,77 & 441,33 & 16,2 \\
\hline PI $\left(\mathrm{kg} \mathrm{ha}^{-1}\right)$ & 1024,35 & 37,42 & 597,34 & 21,93 \\
\hline \multicolumn{5}{|c|}{ Chemical Quality Indicators } \\
\hline $\mathrm{AM}\left(\mathrm{g} \mathrm{kg}^{-1}\right)$ & 101,94 & 24,09 & 62,95 & 6,76 \\
\hline PT $\left(\mathrm{g} \mathrm{kg}^{-1}\right)$ & 66,87 & 17,8 & 244,9 & 28,31 \\
\hline FT $\left(\mathrm{g} \mathrm{kg}^{-1}\right)$ & 12,68 & 5,99 & 356,55 & 38,31 \\
\hline $\mathrm{FDN}\left(\mathrm{g} \mathrm{kg}^{-1}\right)$ & 117,94 & 27,87 & 108,14 & 19,62 \\
\hline $\mathrm{CZ}\left(\mathrm{g} \mathrm{kg}^{-1}\right)$ & 74,21 & 15,54 & 87,17 & 9,36 \\
\hline $\mathrm{EN}\left(\mathrm{MJ} \mathrm{kg}^{-1}\right)$ & 49,43 & 8,68 & 70,88 & 7,61 \\
\hline
\end{tabular}

$\mathrm{GY}=$ grain yield; $\mathrm{BY}=$ biomass yield; $\mathrm{SY}=$ straw yield; $\mathrm{HI}=$ harvest index; $\mathrm{TGM}=$ thousand grain mass; $\mathrm{HM}=$ hectolitre mass; $\mathrm{NG}>2 \mathrm{~mm}=$ number of grains larger than two millimeters; HUI = husking index; IY = industrial yield; $\mathrm{ST}=$ starch; $\mathrm{TP}=$ total protein; $\mathrm{TF}=$ total fiber; $\mathrm{NDF}=$ neutral detergent fiber; $\mathrm{ASH}=$ ash; $\mathrm{EN}=$ energy.

In the indicators of industrial quality (Table 5), the major contribution by the use of biostimulants is in the expression of grain yield, husking index and industrial yield, regardless of the favorable or unfavorable crop year. This condition shows a certain stability 
of these variables compared to the similarity of the results obtained in the years tested. In the chemical quality indicators (Table 5), the major change contribution is on the expression of total protein and neutral detergent fiber in both years of evaluation. It was also found that in unfavorable year (2017) there is effective contribution of starch expression, however, in favorable year (2016) this fact did not happen, directing a greater contribution to expression of total fiber. These facts in some ways indicate that in the unfavorable condition the energy accumulated via starch is more rapidly transformed, possibly used for other biological routes and processes, into more restrictive growing conditions.

In general, considering all the analyzed variables of each indicator, treatment 5 of Glutamin Extra biostimulant applied along with the first and second fungicide application showed the best technical results. This product comprises the formulation involving the combination of macro and micronutrients together with organic carbon and 3\% concentration glutamic acid (Table 1). Although it is the product with the lowest use of glutamic acid, the combination with nutrients showed synergisms to bring more advantageous results. On the other hand, although the technical efficiency has been proven, there is a strong dependence on the agricultural year condition, not guaranteeing the effectiveness of the biostimulant action. Moreover, considering the commercialization value of this product, of U\$ 6.10 per liter, the economic efficiency is not verified, that is, it is not feasible due to the small increases obtained in grain yield, especially considering the other costs involved in the biostimulant application process.

Biostimulants are a mixture of two or more plant regulators or plant regulators with other biochemical substances, such as amino acids, vitamins and nutrients (Castro \& Vieira, 2001; Kolling et al., 2016). The use of biostimulant may be an alternative to assist plants in overcoming abiotic stresses, as they act as hormonal and nutritional enhancement and stimulate root system development (Oliveira et al., 2016; Galindo et al., 2019). These products can be used in both seed treatment and sowing furrows and / or foliar sprays contributing to improved soil physicochemical properties, plant uptake, translocation and nutrient use, including increased resistance to abiotic stresses, and can be used at various stages of plant development (Du Jardin, 2015; Ribeiro et al., 2017). The application of plant regulators in the early stages of seedling development, as well as their use in seed treatment, can stimulate root growth, acting to accelerate seedling recovery under unfavorable conditions such as water deficit (Carvalho et al., 2013; Oliveira et al., 2016). The seed treatment with micronutrients has the advantages of better application uniformity, good utilization by the plant and, mainly, cost reduction (Luchese et al., 2004; Martins et al., 2016). Micronutrient seed treatment has shown significant results, especially in regions that adopt high levels of technology and crop management (Ávila et al., 2006; Martins et al., 2016). These products act in the degradation of seed reserve substances, in cell differentiation, division and elongation assisting in germination (Castro \& Vieira, 2001; Rezende et al., 2017).

The use of biostimulants as an agronomic technique to improve the productivity of various crops has grown in recent years (Binsfeld et al, 2014; Martins et al., 2016). The hormones contained in biostimulants are signaling molecules, among them the use of algae of 
Ascophyllum nodosum species, having auxins, cytokines, gibberellins, abscisic acid and compounds capable of stimulating the production of these hormones naturally (Martins et al., 2016; Ribeiro et al., 2017). In this perspective, the use of plant growth regulators has attracted increasing attention in agriculture as growing techniques evolve, especially in crops of great economic importance (Binsfeld et al, 2014; Galindo et al., 2019). It is noteworthy that a considerable portion of the more than 15 million metric tons of seaweed harvested annually is used as a biostimulant in agriculture (Khan et al., 2009; Galindo et al., 2019). In the European community, the use of commercial algae extract-based products via foliar or soil application is frequent, including in organic agriculture (Mógor et al., 2008; Ribeiro et al., 2017). In Brazil, the use of seaweed extract is regulated by Decree 4,954 as a complexing agent in fertilizer formulations for foliar application and fertigation (Brasil, 2004). This category also includes L-glutamic acid, an amino acid that can be produced by the fermentation of sugarcane molasses by the bacterium Corynebacterium glutamicum (Dreyer et al., 2000; Roder et al., 2016).

Glutamic acid represents a molecular compound that is a precursor of other amino acids and that plays a role in plant metabolism (Guimarães et al., 2015; Roder et al., 2016). Therefore, commercial products involving the use of glutamic acid Glutamin rely on the presence of organic and mineral acids. Studies carried out in several regions of Brazil suggest the occurrence of deficiency or acute toxicity of various elements in the soil, being Mo, Co, $\mathrm{Zn}$, $\mathrm{Cu}, \mathrm{Mn}$ and $\mathrm{B}$ the most frequent deficiency, especially in Cerrado soils (Sfredo \& Oliveira, 2010; Binsfeld et al., 2014). Thus, biofertilizers are characterized as an alternative to supplementation of these nutrients and can be applied via soil in the seed treatment, irrigation systems or foliar spraying. When applied to seed treatment they are adhered to the seed to minimize micronutrient deficiency problems during germination, development and grain production processes (Nicchio et al., 2013; Martins et al., 2016). Among the most used micronutrients in seed treatment are Co, Mo and $\mathrm{Zn}$, and molybdenum plays an indispensable role in the assimilation of nitrate absorbed by plants, thus any deficiency of the element can compromise the metabolism of nitrogen, reducing the crop yield (Ferreira et al., 2007; Binsfeld et al, 2014).

In studies by Carvalho et al. (2013) no positive results were observed in the development of bean seedlings with the application of the amino acid L-glutamic acid via seed treatment. By using these biostimulants via leaf, Pavezi et al. (2017) observed a greater number of pods and root length. Still, Oliveira et al. (2017) concluded that the use of biostimulants in seed and leaf treatment provided better development of cackrey plants. It is noteworthy that the response of crops to treatment with biostimulants is dependent on environmental condition and nutrient availability (Binsfeld et al., 2014; Kolling et al., 2016). However, the increased use of biofertilizers is closely linked to advances in growing technologies and the promotion of higher productivity with stability, aiming at mitigating the limiting factors of production such as weather conditions, pests and diseases. Moreover, in the proposal to develop agriculture that is less dependent on industrialized products, due to higher prices of agrochemicals and more sustainable management, reducing environmental impacts (Aseri et al., 2008; Perin et al., 2016). 


\section{Conclusion}

1. The foliar application of biostimulants with the presence of glutamic acid and nutrients may have positive effects on variables related to yield and industrial and chemical quality of oat grains, however, depending on the agricultural year conditions.

2. The application of Glutamin Extra in the 1st and 2nd fungicide application shows the best results in the vast majority of grain yield and quality variables, however, the costs involving only biostimulants do not guarantee economic viability.

\section{Acknowledgement}

To CAPES, CNPq, FAPERGS, IFRS and UNIJUÍ for resources in the development of research and Scientific Initiation, Technology and Research Productivity scholarships.

\section{References}

Almeida, A. S., Tillmann, M. Â. A., Villela, F. A., \& Pinho, M. S. (2009). Bioativador no desempenho fisiológico de sementes de cenoura. Revista Brasileira de Sementes, 31(3), 87-95. https://doi.org/10.1590/S0101-31222009000300010

Arenhardt, E. G., Silva, J. A. G., Arenhardt, L. G., Silva, D. R., Gzergorczick, M. E., Ceolin, G. P., ... Oliveira, A. C. (2017). Techinical and agronomic efficiency of oat cultivars as a function of nitrogen availability. Científica Jaboticabal, 45(3), 257-270. https://doi.org/10.15361/1984-5529.2017v45n3p257-270

Arenhardt, E. G., Silva, J. A. G., Gewehr, E., Oliveira, A. C., Binelo, M. O., Valdiero, A. C., ... Lima, A. R. C. (2015). The nitrogen supply in wheat cultivation dependent on weather conditions and succession system in southern Brazil. African Journal of Agricultural Research, 10, 4322-4330. https://doi.org/10.5897/AJAR2015.10038

Arf, O., Nascimento, V. do., Rodrigues, R. A. F., Alvarez, R. de C. F., Gitti, D. de C., \& Sá, M. E. de. (2012). Uso de etil-trinexapac em cultivares de arroz de terras altas. Pesquisa Agropecuária Tropical, 42(2), 150-158. https://doi.org/10.1590/S1983-40632012000200008

Aseri, G. K., Jain, N., Panwar, J., Rao, A. V., \& Meghwal, P. R. (2008). Biofertilizers improve plant growth, fruit yield, nutrition, metabolism and rhizosphere enzyme activities of Pomegranate (Punica granatum L.) in Indian Thar Desert. Scientia Horticulturae, (117), 130-135. https://doi.org/10.1016/j.scienta.2008.03.014

Ávila, M. R., Braccini, A. de L., Scapim, C. A., Martorelli, D. T., Albrecht, L. P., \& Faciolli, F. S. (2006). Qualidade fisiológica e produtividade das sementes de milho tratadas com micronutrientes e cultivadas no período de safrinha. Acta Scientiae Agronomy, 28(4), 535-543. https://doi.org/10.4025/actasciagron.v28i4.927

Binsfeld, J. A., Barbieri, A. P. P., Huth, C., Cabrera, I. C. C., \& Henning, L. M. M. (2014). Uso de bioativador, bioestimulante e complexo de nutrientes em sementes de soja. Pesquisa Agropecuária Tropical, 44(1), 88-94. https://doi.org/10.1590/S1983-40632014000100010

Brasil (2004). Ministério da Agricultura, Pecuária e Abastecimento. Decreto n. 4954, de 14 de 
janeiro de 2004. Aprova o Regulamento da Lei n ${ }^{\circ}$ 6.894, de 16 de dezembro de 1980, que dispõe sobre a inspeção e fiscalização da produção e do comércio de fertilizantes, corretivos, inoculantes ou biofertilizantes destinados à agricultura, e dá outras providências. Diário Oficial da União, Brasília, DF.

Brezolin, A. P., Silva, J. A. G. da., Frantz, F. C. R., Binelo, M. O., Valdiero, A. C., Zimmer, C. M., ... Mazurkievicz, G. (2016). The efficiency of wheat yields by nitrogen dose and fractionation. African Journal of Agricultural Research, 11(36), 3440-3449. https://doi.org/10.5897/AJAR2016.11249

Carvalho, N. L., \& Zabot, V. (2012). Nitrogênio: Nutriente ou poluente?. Revista Eletrônica em Gestão, Educação e Tecnologia Ambiental, 6(6), 960-974. https://doi.org/10.5902/223611704671

Carvalho, T. C. de., Silva, S. S. da., Silva, R. C. da., Panobianco, M., \& Mógor, A. F. (2013). Influence of biostimulants on germination and seedling development of Phaseolus vulgaris in water restriction. Revista de Ciências Agrárias, 36(2), 199-205.

Castro, G. S. A., Costa, C. H. M., \& Ferrari Neto, J. (2012). Ecofisiologia da aveia branca. Scientia Agraria Paranaensis, 11, 1-15.

https://doi.org/10.18188/1983-1471/sap.v11n3p1-15

Castro, P. R. C., \& Vieira, E. L. (2001). Aplicações de reguladores vegetais na agricultura tropical. Guaíba, BR: Editora Agropecuária, p. 132.

Cruz, C. D. Programa Genes: Estatística experimental e matrizes. UFV, 2006.

Domingos, C. da. S., Lima, L. H. da S., \& Braccini, A. L. (2015). Nutrição mineral e ferramentas para o manejo da adubação na cultura da soja. Scientia Agraria Paranaensis, 14(3), 132-140. https://doi.org/10.18188/1983-1471/sap.v14n3p132-140

Dornelles, E. F., Kraisig, A. R., Silva, J. A. G. da., Sawicki, S., Roos-Frants, F., \& Carbonera, R. (2018). Artificial intelligence in seeding density optimization and yield simulation for oat. Revista Brasileira de Engenharia Agrícola e Ambiental, 22(3), 183-188. https://doi.org/10.1590/1807-1929/agriambi.v22n3p183-188

Dreyer, A., Coello, N., \& Mondiel, E. (2000). Utilización de la metodologia de superfície de respuesta de la optimización de um medio de cultivo para la producción de L-lisin por Corynebacterium glutamicum. Agronomía Tropical, 50, 167-88.

Du Jardin, P. (2015). Plant biostimulants: Definition, concept, main categories and regulation. Scientia Horticulturae, 196, 3-14. https://doi.org/10.1016/j.scienta.2015.09.021

Ferreira, L. A., Oliveira, J. A., Von Pinho, É. V. de. R., \& Queiroz, D. L. de. (2007). Bioestimulante e fertilizante associados ao tratamento de sementes de milho. Revista Brasileira de Sementes, 29(2), 80-89. https://doi.org/10.1590/S0101-31222007000200011

Forde, B. G., \& Lea, P. J. (2007). Glutamate in plants: metabolism, regulation, and signaling. Journal of Experimental Botany, 58(9), 2339-2358. https://doi.org/10.1093/jxb/erm121 
Galindo, F. S., Teixeira Filho, M. C. M., Buzetti, S., Alves, C. J., Garcia, C. M. de. P., \& Nogueira, L. M. (2019). Extrato de algas como bioestimulante na nutrição e produtividade do trigo irrigado na região de Cerrado. Colloquium Agrariae, 15(1), 130-140. https://doi.org/10.5747/ca.2019.v15.n1.a277

Guimarães, I. P., Paiva, E. P., Almeida, J. P. N., Arrais, I. G., Cardoso, I. A., \& Sá, F. V. S. (2015). Production of Seedling of three accessions of papaya under increasing dose of Biostimulant Revista de Ciências Agrárias, 38(3), 414-421.

Hawerroth, M. C., Carvalho, F. I. F., Oliveira, A. C., Silva, J. A. G. da., Gutkoski, L. C., Sartori, J. F., ... Hawerroth, F. J. (2013). Adaptability and stability of white oat cultivars as to chemical composition of the caryopsis. Pesquisa Agropecuária Brasileira, 48(1), 42-50. https://doi.org/10.1590/S0100-204X2013000100006

Hawerroth, M. C., Silva, J. A. G. da., Souza, C. A., Oliveira, A. C. de., Luche, H. de. S., Zimmer, C. M., ... Sponchiado, J. C (2015). Redução do acamamento em aveia-branca com uso do regulador de crescimento etil-trinexapac. Pesquisa Agropecuária Brasileira, 50(2), 115-125. https://doi.org/10.1590/S0100-204X2015000200003

Henrichsen, L., Scremin, A. H., Dornelles, E. L., Kraisig, A. R., Mamann, A. T. W., Brezolin, A. P., ... Silva, J. A. G. (2018). Regressão na Eficiência de Uso de Nitrogênio em Aveia pelo Biopolímero Hidrogel. Proceeding Series of the Brazilian Society of Applied and Computational Mathematics, 6(1).

Khan, W., Rayirath, U. P., Subramanian, S., Jithesh, M. N., Rayorath, P., Hodges, D. M., ... Prithiviraj, B. (2009). Seaweed extracts as biostimulants of plant growth and development. Journal of Plant Growth Regulation, 28, 386-399.

https://doi.org/10.1007/s00344-009-9103-X

Kolling, D. F., Sangoi, L., Souza, C. A., Schenatto, D. E., Giordani, W., \& Boniatti, C. M. (2016). Tratamento de sementes com bioestimulante ao milho submetido a diferentes variabilidades na distribuição espacial das plantas. Ciência Rural, 46(2), 248-253. https://doi.org/10.1590/0103-8478cr20150504

Luchese, A. V., Gonçalves Júnior, A. C., Luchese, E. B., \& Braccini, M. do C. L. (2004). Emergência e absorção de cobre por plantas de milho (Zea mays) em resposta ao tratamento de sementes com cobre. Ciência Rural, 34(6), 1949-1952.

https://doi.org/10.1590/S0103-84782004000600044

Maluf, H. J. G. M., Soares, E. M. B., Silva, I. R.; Neves, J. C. L., \& Silva, M. F. O. (2015). Disponibilidade e recuperação de nutrientes de resíduos culturais em solo com diferentes texturas. Revista Brasileira de Ciência do Solo, 39, 1690-1702. https://doi.org/10.1590/01000683rbcs20140658

Mandal, S., Thangarajan, R., Bolan, N. S., Sarkar, B., Khan, N., Sik Ok, Y., \& Naidu, R. (2016). Biochar-induced concomitante decrease in ammonia volatilization and increase in nitrogen use efficiency by wheat. Chemosphere, 142, 120-127.

https://doi.org/10.1016/j.chemosphere.2015.04.086 
Mantai, R. D., Silva, J. A. G. da., Arenhardt, E. G., Sausen, A. T. Z. R., Binello, M. O., Bianchi, V., Silva, D. R., \& Bandeira, L. M. (2016 a). The Dynamics of Relation Oat Panicle with Grain Yield by Nitrogen. American Journal of Plant Sciences, 7(1), 17. https://doi.org/10.4236/ajps.2016.71003

Mantai, R. D., Silva, J. A. G., Arenhardt, E. G., Heck, T. G., Sausen, A. T. Z. R., Krüger, C. A. M. B., ... Krysczun, D. K. (2015). The effect of nitrogen dose on the yield indicators of oats. African Journal of Agricultural Research, 10(39), 3773-3781.

https://doi.org/10.5897/AJAR2015.9845

Mantai, R. D., Silva, J. A. G., Arenhardt, E. G., Scremin, O. B., Mamann, Â. T. W., Frantz, R. Z., ... Krysczun, D. K. (2016 b). Simulation of oat grain (Avena sativa) using its panicle components and nitrogen fertilizer. African Journal of Agricultural Research, 11, 3975-3983. https://doi.org/10.5897/AJAR2016.10943

Marolli, A., Silva, J. A. G. da., Sawicki, S., Binelo, M. O., Scremin, A. H., Reginatto, D. C., ... Lambrecht, D. M. (2018). A simulação da biomassa de aveia por elementos climáticos, nitrogênio e regulador de crescimento. Arquivo Brasileiro de Medicina Veterinária e Zootecnia, 70(2), 535-544. https://doi.org/10.1590/1678-4162-9504

Marolli, A., Silva, J. A. G., Romitti, M. V., Mantai, R. D., Scremin, O. B., Frantz, R. Z., ... Lima, A. R. C. (2017). Contributive effect of growth regulator Trinexapac-Ethyl to oats yield in Brazil. African Journal of Agricultural Research, 12, 795-804.

https://doi.org/10.5897/AJAR2016.11784

Martins, D. C., Borges, I. D., Cruz, J. C., \& Martins Netto, D. A. (2016). Produtividade de duas cultivares de milho submetidas ao tratamento de sementes com bioestimulantes fertilizantes líquidos e Azospirillum sp. Revista Brasileira de Milho e Sorgo, 15(2), 217-228. https://doi.org/10.18512/1980-6477/rbms.v15n2p217-228

Microquímica. Especificações Técnicas. Available at:

<https://www.microquimica.com/site/produtos/30/biomol>, Accessed on: May 5th, 2017.

Mógor, Á. F., Ono, E. O., Rodrigues, J. D., \& Mógor, G. (2008). Aplicação foliar de extrato de alga, ácido l-glutâmico e cálcio em feijoeiro. Scientia Agrária, 9(4), 431-437. https://doi.org/10.5380/rsa.v9i4.11710

Nicchio, B., Boer, C. A., Siqueira, T. P., Vasconcelos, A. C., Resende, W. S., \& Lana, R. M. Q. (2013). Ácido húmico e bioativador no tratamento de sementes de milho. Journal of Agronomic Sciences, 2(2), 61-73.

Oliveira, A. de. O., Medeiros, J. F. de., Cunha, R. C. da, Souza, W. de. L., \& Lima L. A. (2016). Uso de bioestimulante como agente amenizador do estresse salino na cultura do milho pipoca. Revista Ciência Agronômica, 47(2), 307-315.

Oliveira, F. A., Oliveira, J. M., Souza Neta, M. L., Oliveira, M. K. T., \& Alves, R. C. (2017). Substrato e bioestimulante na produção de mudas de maxixeiro. Horticultura Brasileira, 35(1), 141-146. https://doi.org/10.1590/s0102-053620170122 


\section{$\triangle$ Macrothink}

Journal of Agricultural Studies

ISSN 2166-0379

2020, Vol. 8, No. 2

Olsen, D., Pedó, T., Koch, F., Martinazzo, E. G., Aumonde, T. Z., \& Villela, F. A. (2016). Tratamento de sementes com bioestimulante: vigor e isoenzimas de plântula de arroz de sequeiro sob restrição hídrica, Agrarian, 9(34), 296-302.

Pavezi, A., Favarão, S. C. M., \& Korte, K. P. (2017). Efeito de diferentes bioestimulantes na cultura do feijoeiro-comum. Revista Ciências Exatas e da Terra e Ciências Agrárias, 12(1), $30-35$.

Pereira, D. C., Wilsen Neto, A., \& Nóbrega L. H. P. (2013). Adubação orgânica e algumas aplicações agrícolas. Revista Varia Scientia Agrárias, 03(2), 159-174.

Perin, A., Gonçalves, E. de. L., Ferreira, A. C., Salib, G. C., Ribeiro, J. M. M., Andrade, E. P. de \& Salib, N. C. (2016). Uso de promotores de crescimento no tratamento de sementes de feijão carioca. Global Science and Technology, 09(3), 98-105.

Rezende, G. F., Machado, B. Q. F., Junior, A. de. S., Sousa, L. B. de. \& Lana, R. M. Q. (2017). Efeitos da aplicação de bioestimulantes em sementes de algodão. Revista Verde, 12(1), 177-181. https://doi.org/10.18378/rvads.v12i1.4299

Ribeiro, R. F., Lobo, J. T., Cavalcante, I. H. L., Tenreiro, I. G. P., \& Lima, D. D. (2017). Bioestimulante na produção de mudas de videira cv. Crimson seedless. Scientia Agraria, 18(4), 36-42. https://doi.org/10.5380/rsa.v18i4.50922

Roder, C., Mógor, Á. F., Gemin, L. G., \& Fabbrin, E. G dos. S. (2016). Produção de repolho em sistema orgânico com uso de biofertilizante contendo ácido L-glutâmico. Revista Brasileira de Agroecologia, 1(2), 79-84.

Romitti, M. V., Silva, J. A. G. da., Marolli, A., Arenhardt, E. G., Mamann, Â. T. W.de., Scremin, O. B., ... Bandeira L. M. (2016). The management of sowing density on yield and lodging in the main oat biotype grown in Brazil. African Journal of Agricultural Research, 11(21), 1935-1944. https://doi.org/10.5897/AJAR2016.10909

Scremin, O. B., Silva, J. A. G. da., Mamann, Â. T. W. de., Mantai, R. D., Brezolin, A. P., \& Marolli, A. (2017). Nitrogen efficiency in oat yield through the biopolymer hydrogel. Revista Brasileira de Engenharia Agrícola e Ambiental, 21(6), 379-385.

https://doi.org/10.1590/1807-1929/agriambi.v21n6p379-385

Sfredo, G. J., \& Oliveira, M. C. N. de. (2010). Soja: molibdênio e cobalto. Londrina: Embrapa Soja.

Silva, J. A. G., Arenhardt, E. G., Krüger, C. A. M. B., Lucchese, O. A., Metz, M., \& Marolli, A. (2015). A expressão dos componentes de produtividade do trigo pela classe tecnológica e aproveitamento do nitrogênio. Revista Brasileira de Engenharia Agrícola e Ambiental, 19(1), 27-33. https://doi.org/10.1590/1807-1929/agriambi.v19n1p27-33

Souza, J. L. M., Gerstemberger, E., \& Araujo, M. A. (2013). Calibração de modelos agrometeorológicos para estimar a produtividade da cultura do trigo, considerando sistemas de manejo do solo, em Ponta Grossa-PR. Revista Brasileira de Meteorologia, 28(4), 409-418. https://doi.org/10.1590/S0102-77862013000400007 
Tonin, R. B., Ranzi, C., Camera, J. N., Forcelini, C. A., \& Reis, E. M. (2014). Amplitude térmica para germinação de conídios de Drechslera tritici-repentis. Summa Phytopathologica, 4O(2), 174-177. https://doi.org/10.1590/0100-5405/1881

\section{Copyright Disclaimer}

Copyright for this article is retained by the author(s), with first publication rights granted to the journal.

This is an open-access article distributed under the terms and conditions of the Creative Commons Attribution license (http://creativecommons.org/licenses/by/4.0/). 